\title{
Cleavage of mispaired heteroduplex DNA substrates by numerous restriction enzymes
}

\author{
Mark T. Langhans and Michael J. Palladino \\ Department of Pharmacology and Chemical Biology \\ University of Pittsburgh School of Medicine \\ Pittsburgh, PA 15261 \\ Pittsburgh Institute for Neurodegenerative Diseases \\ University of Pittsburgh School of Medicine \\ Pittsburgh, PA 15260
}

\begin{abstract}
The utility of restriction endonucleases as a tool in molecular biology is in large part due to the high degree of specificity with which they cleave well-characterized DNA recognition sequences. The specificity of restriction endonucleases is not absolute, yet many commonly used assays of biological phenomena and contemporary molecular biology techniques rely on the premise that restriction enzymes will cleave only perfect cognate recognition sites. In vitro, mispaired heteroduplex DNAs are commonly formed, especially subsequent to polymerase chain reaction amplification. We investigated a panel of restriction endonucleases to determine their ability to cleave mispaired heteroduplex DNA substrates. Two straightforward, non-radioactive assays are used to evaluate mispaired heteroduplex DNA cleavage: a PCR amplification method and an oligonucleotide-based assay. These assays demonstrated that most restriction endonucleases are capable of site-specific double-strand cleavage with heteroduplex mispaired DNA substrates, however, certain mispaired substrates do effectively abrogate cleavage to undetectable levels. These data are consistent with mispaired substrate cleavage previously reported for Eco RI and, importantly, extend our knowledge of mispaired heteroduplex substrate cleavage to 13 additional enzymes.
\end{abstract}

\section{Introduction}

Restriction endonucleases are the DNA-cleaving components of restriction modification systems employed by bacteria, archaea and certain viruses of unicellular algae to protect against foreign, invading DNA (Pingoud and Jeltsch, 2001; Pingoud et al., 2005). Restriction endonucleases are classified broadly by subunit composition and cofactor requirement into types I, II, III and IV (Bickle and Kruger, 1993; Perona, 2002; Pingoud et al., 2005). The largest class of restriction endonucleases is type $\mathrm{II}$, which is characterized by homodimeric or homotetrameric assemblies that generally require $\mathrm{Mg}^{+2}$ as a cofactor and recognize and cleave close to or within a 4-8 base pair recognition sequence (Bickle and Kruger, 1993; Pingoud and Jeltsch, 2001; Perona, 2002; Pingoud et al., 2005). Most of the enzymes used in modern molecular biology laboratories -such as in assays of biological phenomena, cloning, mutation detection and site-directed mutagenesis protocols -- are type II endonucleases (Pingoud et al., 1993; Roberts, 2005).
The most valuable attribute of restriction endonucleases is the high degree of specificity with which they recognize and cleave DNA sequences (Roberts, 2005). Understanding the chemical and biophysical basis of this specificity has important biological and biomedical implications: The specificity of protein-DNA interactions underlies a myriad of regulatory and cell biological mechanisms. Crystal structures have been solved for several type II restriction endonucleases, and in some cases, mutant forms. Additionally, some are co-crystals with the enzyme bound to their cognate or noncognate substrates ((Roberts et al., 2007) and sources therein). Biophysical studies using crystallographic data, biochemical and kinetic studies, and molecular dynamics simulations have provided key insights into the proteinDNA interface -- most notably with the EcoRI and EcoRV proteins -- and have provided a foundational understanding of the biophysical basis of site specific interactions (Becker et al., 1988; Lesser et al., 1990; Lesser et al., 1993; Winkler et al., 1993; Engler et al., 1997; Jen-Jacobson, 1997; Horton and Perona, 1998b; Jen-Jacobson, 2000; Watrob et al., 2001; Horton et al., 2002; Parry et al., 2003; Kurpiewski et al., 2004; Hiller et al., 2005).

Many type II restriction endonucleases are known to recognize a symmetrical site within DNA known as a palindrome, however, recently it is becoming increasingly appreciated that this class of enzymes is composed of proteins with a large degree of structural and functional diversity. The two-fold symmetrical relationship of the DNA-protein interface is consistent with the well-supported half-site rotational symmetry model of recognition (Kurpiewski et al., 2004). Functionally, type II restriction enzymes are typically a homodimer where the monomers interface symmetrically with each half-site of the recognition pattern (Alves et al., 1982). Although these enzymes have a high degree of specificity for their cognate recognition sequence, the specificity is not absolute. Extensive, pioneering biophysical studies have demonstrated the molecular basis of non-canonical DNA cleavage: the efficiency of non-canonical substrate cleavage can be predicted once the energetic penalties associated with the changes to the substrate are appreciated (Lesser et al., 1990). Restriction enzymes for which detailed studies of cognate and noncognate substrates have been performed, such as EcoRI, have revealed a dynamic range of dissociation and cleavage rate constants. Cleavage rate constants for noncognate substrates can vary from greater than that of the cognate substrate to a rate so slow that detectable cleavage is not generally observable (Thielking et al., 1990). For the enzymes EcoRV, EcoRI, BamHI the rate of noncognate substrate cleavage has been shown to be exquisitely dependent upon many variables, most notably: in vitro conditions, pH, salt concentrations (Engler et al., 1997), divalent ion concentrations (Thielking et al., 1992; Vermote and Halford, 1992; Vipond and Halford, 1995; 
Engler et al., 2001; Sam et al., 2001; Kurpiewski et al., 2004), the presence of glycerol or other water occluding chemicals (Horton and Perona, 1998b; Sapienza et al., 2005; Sapienza et al., 2007), and the context of the site (adjacent nucleotides and the proximity to other recognition sites or DNA termini) (Alves et al., 1984; Engler et al., 1997; Jen-Jacobson, 1997; Horton and Perona, 1998a; Engler et al., 2001). These factors have widely variable thermodynamic contributions directly and indirectly to both the recognition and cleavage steps of restriction endonucleases (Lesser et al., 1990; Martin et al., 1999; Jen-Jacobson et al., 2000). While it is believed that most restriction enzymes share a common conserved functional protein core (Niv et al., 2007), there is very little primary amino acid sequence homology (Kovall and Matthews, 1999). Even among isochizomers, structural requirements for cleavage vary drastically (Wolfes et al., 1985). The lack of structural conservation suggests that mechanistic inferences between these enzymes should be made with extreme caution. Biophysical data pertaining to the mechanism of recognition and cleavage among type II restriction enzymes is currently limited to a few well-studied enzymes, making it exceptionally difficult to predict mechanistic characteristics or the rate of noncognate substrate cleavage of the many lesser-studied type II restriction enzymes.

Heteroduplex DNA is not common in vivo: DNA mismatches are readily detected and repaired (Modrich, 1995). However, mismatch heteroduplex DNA is commonly found in vitro, especially when there is heterogeneity in the DNA and PCR is used to amplify the DNA. This had been elegantly demonstrated by T4 endonuclease VII sensitivity of mixed template PCR amplicons (Jenkins et al., 1999). T4 endonuclease VII has been shown to efficiently cleave mismatched DNA heteroduplexes (Golz et al., 1998a; Golz et al., 1998b). Assays utilized to quantify biological phenomena, such as the frequency of mutation, recombination or RNA editing, or common molecular biology techniques, such as sitedirected mutagenesis protocols, must address the issue of heteroduplex DNA when PCR amplification is employed. However, often assays utilize PCR and subsequently quantify the frequency of restriction endonuclease cleavage as a metric of a biological phenomenon, without controlling for heteroduplex DNAs. Numerous reports quantify restriction endonuclease cleavage in assays that ignore heteroduplex DNA formation or assume (sometimes this assumption is explicitly stated) that heteroduplex DNA will not be a viable substrate for double strand DNA cleavage (Iland and Todd, 1992; Paschen and Djuricic, 1994; Belcher and Howe, 1997; Judo et al., 1998; Serth et al., 1998; Jenkins et al., 1999). Protocols used to perform in vitro sitedirected mutagenesis, namely the unique site elimination (USE) method, also assume heteroduplex DNA will not be cleaved by restriction endonucleases (Deng and Nickoloff, 1992; Ling and Robinson, 1997; Clontech Laboratories, 2001). The assumption that a heteroduplex restriction sequence is not a viable substrate for cleavage is inconsistent with available structural and biophysical data suggesting that many non-cognate substrates may be efficiently cleaved in vitro, such as has been shown for the EcoRI endonuclease (Thielking et al., 1990). We investigated whether cleavage of mispaired heteroduplex
DNA substrates was unique to EcoRI or was more widespread among commonly used restriction endonucleases. Both position and type of non-cognate change within the recognition sequence are used to empirically probe the DNA-protein interface for critical alterations that either permit or abrogate efficient cleavage.

\section{Results \\ Heteroduplex DNA cleavage revealed by PCR assay}

Site selectivity of restriction endonucleases is a key property that has made these proteins extraordinarily useful in molecular biology. Despite their widespread use experimentally, a detailed understanding of the biophysical basis of this specificity has only been studied for a few enzymes, most notably EcoRI, EcoRV and BamHI (Perona, 2002). Due to the large degree of size and structural diversity of restriction endonucleases (Pingoud et al., 2005), inferences among enzymes should only be made with caution. In vivo, restriction enzyme recognition sites in DNA are almost always perfect cognate homoduplexes where the site (often a palindrome) exists on both strands of the DNA. Typically recognition of the two cognate DNA half-sites by the endonuclease (most often a dimer) results in specific double-stranded cleavage. In vitro, heteroduplex DNA can be quite common where one half-site may exist but the other half-site has a mismatch (thus the sequence is correct on only one strand). We asked whether such noncognate sites would be recognized by restriction endonucleases and double-strand cleavage would occur. We developed a PCR-based assay to test whether heteroduplex restriction enzyme recognition sites with a single nucleotide mispair could be cleaved by various endonucleases. The assay utilizes a forward primer encoding the restriction endonuclease recognition site or a non-cognate site bearing a single nucleotide substitution and a reverse primer to produce an $\sim 300$ based-pair amplicon from a plasmid template. The amplicons were quantified by absorption spectrometry, mixed equimolar, denatured, and annealed to ensure optimal formation of heteroduplex DNA ( $50 \%)$. The annealed amplicons were utilized as substrate in a restriction endonuclease reaction and the products were resolved using agarose gel electrophoresis (Figure 1A). Control homoduplex samples with (+) and without (-) the cognate restriction recognition site were also tested. Because the heteroduplex substrate is $\sim 1 / 4$ homoduplex ,$+ \sim 1 / 4$ homoduplex - , and $\sim 1 / 2$ heteroduplex DNA, a cleavage pattern of $3 / 4$ cutting and $1 / 4$ resistant is consistent with efficient heteroduplex cleavage. The Eco0109I restriction endonuclease did not significantly cleave the heteroduplex DNA (Figure 1A). However, the other three enzymes examined, Ahdl, Pmel and AlwNI, all produced a fragment pattern consistent with cleavage of some or all of the heteroduplex DNA (Figure 1A). Densitometry was performed on reactions performed in triplicate and Chi Square analyses were performed to determine whether the cleavage pattern (ratio of resistant to cleaved) matched that expected if only the homoduplex + DNA were cleaved. Only, Eco0109l produced such a pattern, whereas, Ahdl, Pmel and AlwNI deviated significantly from that expected, suggesting the heteroduplex DNA also underwent significant doublestrand cleavage (Figure 1B). 

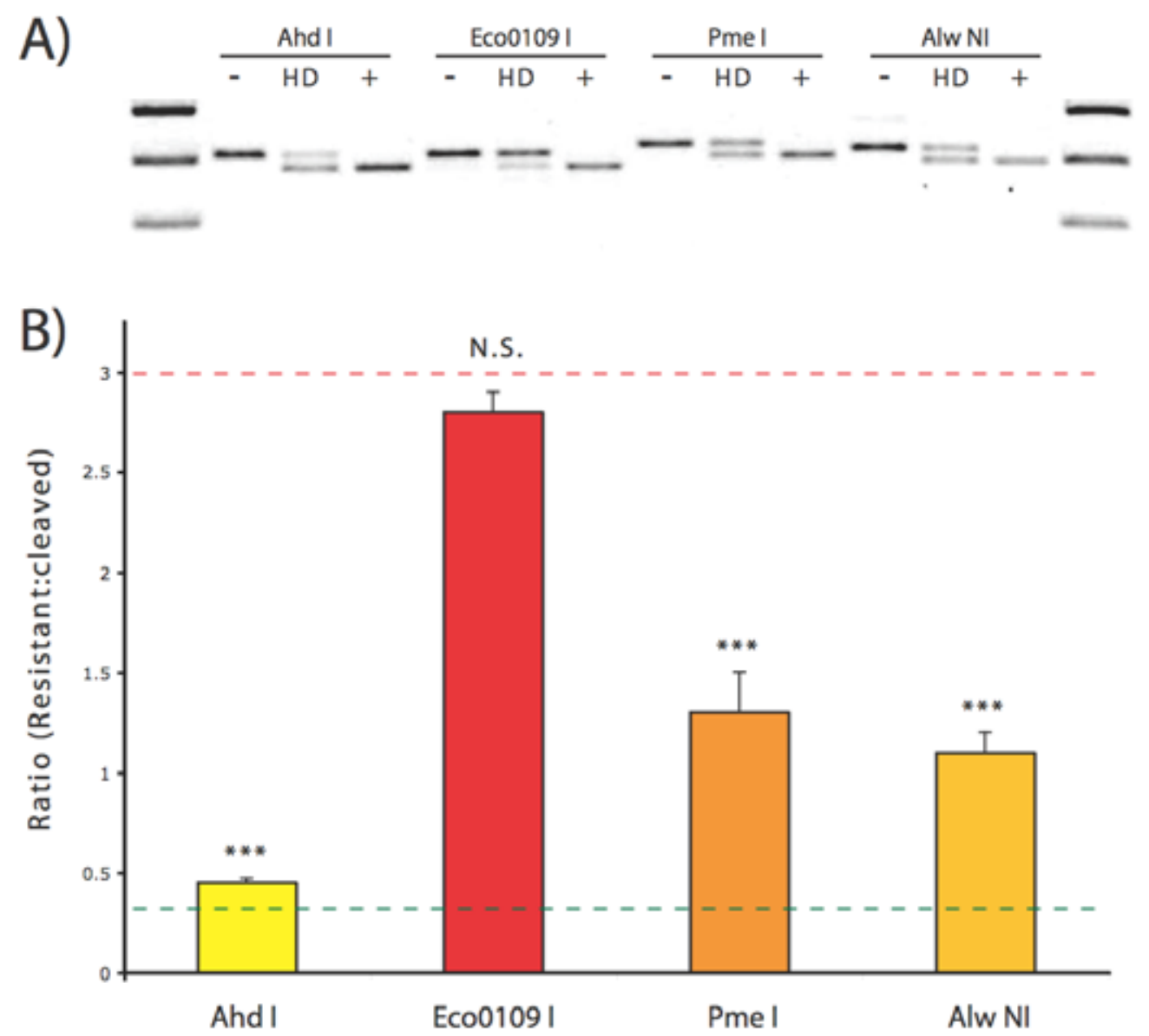

Figure 1: PCR-based assay for heteroduplex DNA cleavage assay. Oligonucleotide PCR amplicons $\sim 300 b p$ in length were amplified containing the recognition site $(+)$ or with a single nucleotide substitution (-). These amplicons were used to generate heteroduplex DNA (HD) by annealing an equimolar mixture of + and - products. (A) Each enzyme was tested for cleavage of their recognition site $(+)$, a mutated site (-), and heteroduplex substrates. All enzymes efficiently cleaved the positive control (+) and did not cut the mutated site (-). Mutations examined were Ahdl \#1I, Eco0109I \#3I, Pmel \#3V and AlwNI \#1V mutations were examined. Nomenclature of mutation is the position number in the enzyme recognition sequence and type of change (transition $=1$ and transversion $=\mathrm{V}$ ) and is used throughout. (B) Quantification of the ratio of resistant to cleaved DNA is shown. Enzymes unable to cleave heteroduplex DNA are expected to produce a ratio of resistant to cleaved products equal to 3 (red dashed line), whereas, those efficiently cleaving heteroduplex DNA are expected to give a ratio of 0.33 (green dashed line). Only Eco0109 I produced a pattern that did not deviate significantly from that expected for not cutting heteroduplex ( $p>$ $0.95)$. Ahdl, Pmel and AlwNI each deviated significantly from that expected for no heteroduplex cleavage ${ }^{* * *}$ is $\left.p<0.001\right)$. Statistical analyses were Chi Square tests, $n=3$ for each enzyme.

\section{Oligonucleotide assay of heteroduplex DNA cleavage}

We aimed to develop a more sensitive and quantitative, yet still non-radioactive, assay of mispaired non-cognate heteroduplex DNA cleavage using annealed oligonucleotides. The oligonucleotide assay utilizes custom synthesized and annealed oligonucleotides as the substrate. Reaction products are resolved using nondenaturing polyacrylamide gel electrophoresis (PAGE) and post stained with ethidium bromide for fluorescence analysis. We hypothesized the oligonucleotide heteroduplex assay would confirm our previous results with the PCR assay and yield more sensitive quantitative results, due to the homogeneity of the substrate. We examined three of the enzymes studied using the PCR assay (Ahdl, Eco0109l, and Pmel) and ten additional commonly used restriction enzymes, including: BamHI, EcoRI, EcoRV, HindIII, Pstl, Sacl, Sall, Spel, Xhol, Xbal, all for heteroduplex DNA cleavage with a single mispair. The oligonucleotide assay demonstrated Spel, Ahdl, Pmel and Sacl restriction endonucleases cleave the heteroduplex substrate tested bearing a single noncognate mispair (Figure 2 and data not shown). Xhol,
Xbal, EcoRI and Sall failed to efficiently cleave heteroduplex DNA (Figure 2A and 2B). Densitometry was performed to estimate cleavage efficiency with that of the homoduplex DNA bearing the site. In all cases, the minus enzyme lane did not reveal cleavage products and the homoduplex was robustly cleaved. The assays revealed Spel, Pmel and Sacl produced robust heteroduplex cleavage with Pmel and Sacl approaching the efficiency of homoduplex cleavage in this assay (Figure 2C-E). Importantly, results obtained using the PCR-based heteroduplex DNA cleavage assay were confirmed with the oligonucleotide assay (Figure $2 \mathrm{E}$ and data not shown).

\section{Position and mutation type effect on heteroduplex DNA cleavage}

Biophysical studies of certain restriction enzyme recognition sites have established a hierarchy of noncognate substrate viability from better than the cognate substrate to not a viable substrate at all (Perona, 2002). Mismatched substrates for the EcoRI enzyme are generally considerably better substrates than those 
bearing the alteration on both strands of the DNA. However, the specific alteration in mismatched sequences resulted in wildly varied cleavage rates spanning numerous orders of magnitude (Thielking et al., 1990). Additionally, the position of the alteration, type of alteration, destabilization of the duplex, perturbation of the DNA backbone and even flanking positions outside the recognition sequence have all been shown to affect substrate structure and or cleavage efficiency (Alves et al., 1984; Wenz et al., 1996; Engler et al., 1997; JenJacobson, 1997; Horton and Perona, 1998a). We examined the effect of position and mutation type on heteroduplex DNA cleavage while maintaining the context of the site constant. There are 18 possibly single mismatch substrates for a restriction endonuclease with a hexanucleotide recognition sequence when restricting the analysis to the common four DNA nucleotides. We reasoned that examining six mispaired substrates for each restriction endonuclease would efficiently estimate the frequency with which mispaired non-cognate substrates are cleaved. To initially probe the requirements of heteroduplex DNA cleavage activity, we generated alterations in each position, testing individually three transitions (I) and three transversions (V) in the recognition site (alternating where practical) and examined cleavage patterns using the oligonucleotide assay (Figure 3). Most of the enzymes examined produced readily detectable double-stranded cleavage fragments and, as predicted, none of the enzymes cleaved all of the mispaired heteroduplex DNA substrates tested (Figure 3 and Table 1). In all cases, double-strand cleavage of the homoduplex control was observed to be efficient (Figure 3). Importantly, none of the enzymes cleaved all of the mispaired substrates, ruling out contamination with a non-specific mismatch endonuclease. Interestingly, Spel was found to robustly cleave heteroduplex DNA with transitions at positions 1, 3 or 5 , but transversions at any position were cleaved less efficiently (Figure 3A). Although there was no strong position effect observed for Spel, a mutation type preference was evident. In contrast, Sacl revealed a strong position effect but no mutation type preference was observed (Figure 3B). Sacl robustly cleaved heteroduplex DNA with transitions at positions 3 or 6 and transversions at positions 1 or 2 , however, neither the transition at position 4 or the transversion at position 5 were viable substrates (Figure 3B). We extended our heteroduplex substrate position effect experimentation to include six other restriction endonucleases: Xbal, EcoRI, EcoRV, Xhol, BamHI, and HindIII. These experiments identified numerous additional sites where heteroduplex changes either permitted cleavage or abrogated cleavage (Figure $3 \mathrm{C}-\mathrm{H}$ and Table 1). Some heteroduplex conditions, such as EcoRV $4 \mathrm{I} /+$ and $6 \mathrm{I} /+$, EcoRI $1 \mathrm{~V} /+$, Xhol $1 \mathrm{~V} /+$ and $2 \mathrm{I} /+$, and $\mathrm{BamHI} 3 \mathrm{I} /+$ and $6 \mathrm{~V} /+$, were efficiently cleaved, whereas, other heteroduplex substrates revealed minimal to no cleavage in these assays.
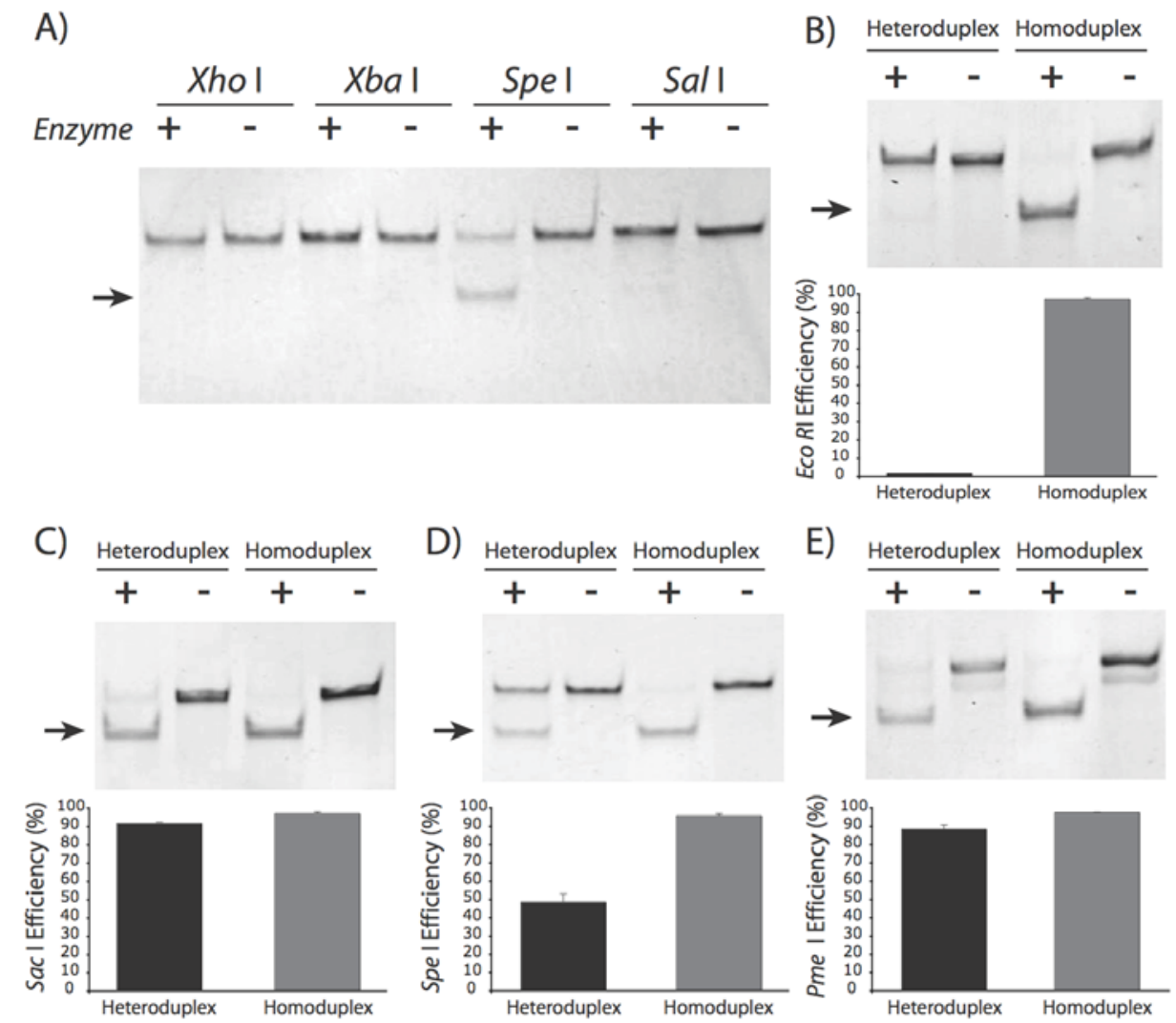

Figure 2: Oligonucleotide heteroduplex DNA cleavage assay. Annealed oligonucleotides bearing the restriction recognition site $($ homoduplex $=+/+$ ) or lacking the site on one strand (heteroduplex = HD) were tested for DNA cleavage with various restriction enzymes. (A) Spel \#1I / + heteroduplex results in double stranded cleavage, producing a $\sim 25$ bp fragment. Xhol \#6I/+, Xbal \#2/+, and Sall \#2I/+ heteroduplexes show no evidence of cleavage. (B-E) Quantified cleavage efficiency for homoduplex and heteroduplex DNAs from 3 or more independent reactions. (B) EcoRI \#5V/+ heteroduplex is minimally cleaved. (C) Sac I \#1V/+ heteroduplex is efficiently cleaved. (D) Spe I \#1I/+ heteroduplex resulted in 50\% cleavage relative to homoduplex controls. (E) Pme I \#6I/+ heteroduplex also cleaved efficiently. + and - indicate whether an enzyme was included in the restriction endonuclease reaction. $+/+$ substrate resulted in efficient cleavage for all enzymes examined. Arrows indicate cleavage fragment. 
Table 1: Summary of heteroduplex DNA cleavage activity for each restriction endonuclease. The positions examined for each type of non-cognate change are shown in parentheses and whether these were cleaved is indicated. G.C.T. (Glycerol concentration test) indicates whether heteroduplex cleavage requires or is stimulated by high glycerol concentrations.

\begin{tabular}{lllll}
\hline Enzyme & Transition (I) & Transversion (V) & Assay(s) & G.C.T. \\
\hline AlwNI & N.E. & Yes $(1)$ & PCR & N.E. \\
Ahdl & Yes (1) & Yes $(1)$ & PCR \& Oligonucleotide & N.E. \\
BamHI & No $(1,5)$ Yes $(3)$ & No $(2,4,5)$ Yes $(6)$ & Oligonucleotide & No \\
Eco0109I & No $(3)$ & No $(3)$ & PCR \& Oligonucleotide & N/A \\
EcoRI & Yes $\left(5^{\ddagger, *}\right)$ No $(2,4,6)$ & Yes $\left(1^{*}\right)$ No $(3,5)$ & Oligonucleotide & Yes \\
EcoRV & Yes $(3,4,6)$ No $(2)$ & Yes $(5)$ No $(1,3)$ & Oligonucleotide & No \\
HindlII & No $(1,2,3,5)$ & No $(2,4,6)$ & Oligonucleotide & N/A \\
Pmel & Yes $(5,6)$ & Yes $(5)$ & PCR \& Oligonucleotide & N.E. \\
Pstl & No $(3)$ & No $(3)$ & Oligonucleotide & N/A \\
Sacl & Yes $(3,6)$ No $(4)$ & Yes $(1,2)$ No $(5)$ & Oligonucleotide & No \\
Sall & No $(2)$ & No $(2)$ & Oligonucleotide & N/A \\
Spel & Yes $(1,3,5)$ & No $\left(2,4,6^{\ddagger}\right)$ & Oligonucleotide & No \\
Xbal & No $(1,2,3,5)$ & No $(2,4)$ Yes $(6)$ & Oligonucleotide & Yes \\
Xhol & Yes $(2)$ No $(4,6)$ & Yes $(1,6)$ No $(3,5)$ & Oligonucleotide & No
\end{tabular}

Note: The assay indicates the PCR-based heteroduplex cleavage (PCR) and/ or the oligonucleotide heteroduplex cleavage (Oligo.) assays. $\ddagger=$ modest cleavage detected is $5-15 \%$. ${ }^{*}$ Heteroduplex cleavage at this position is glycerol dependent. No cleavage indicates less $<5 \%$ of the appropriate fragment size was observed. $\mathrm{N} / \mathrm{A}=$ not applicable. N.E. $=$ not examined.

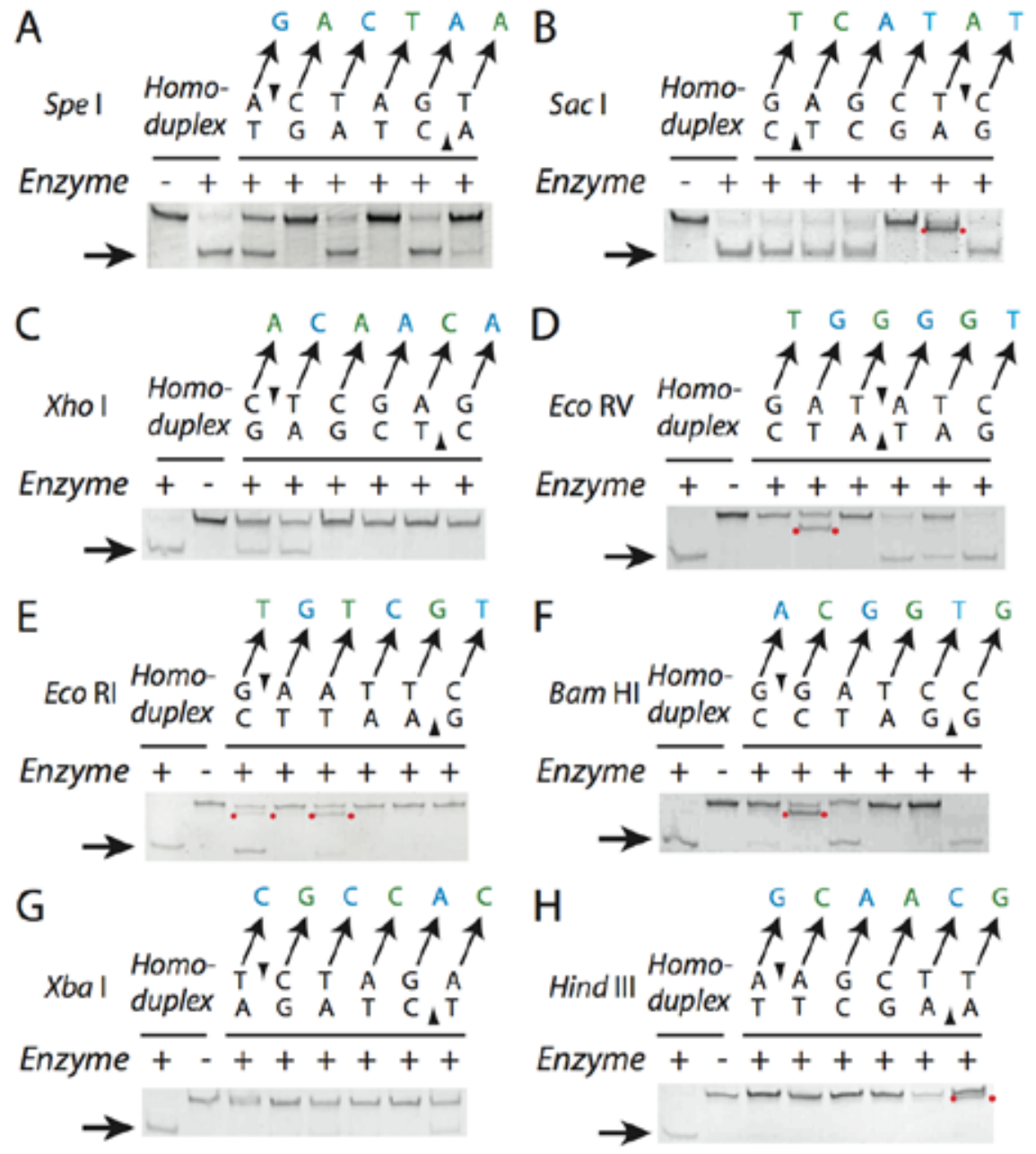

Figure 3: Position effect of heteroduplex DNA cleavage. Position and mutation type affect heteroduplex cleavage differently for each enzyme examined. Three transitions (blue) and three tranversions (green) were examined for each enzyme. Heteroduplex substrates were examined at all six positions for: (A) Spel, (B) Sacl, (C) Xhol, (D) EcoRV, (E) EcoRI, (F) BamHI, (G) Xbal, and (H) Hindlll. Each profile was tested two or more times for each enzyme and representative data are shown. Arrows indicate cleavage fragment. Red bullets highlight intermediate DNA fragment. 

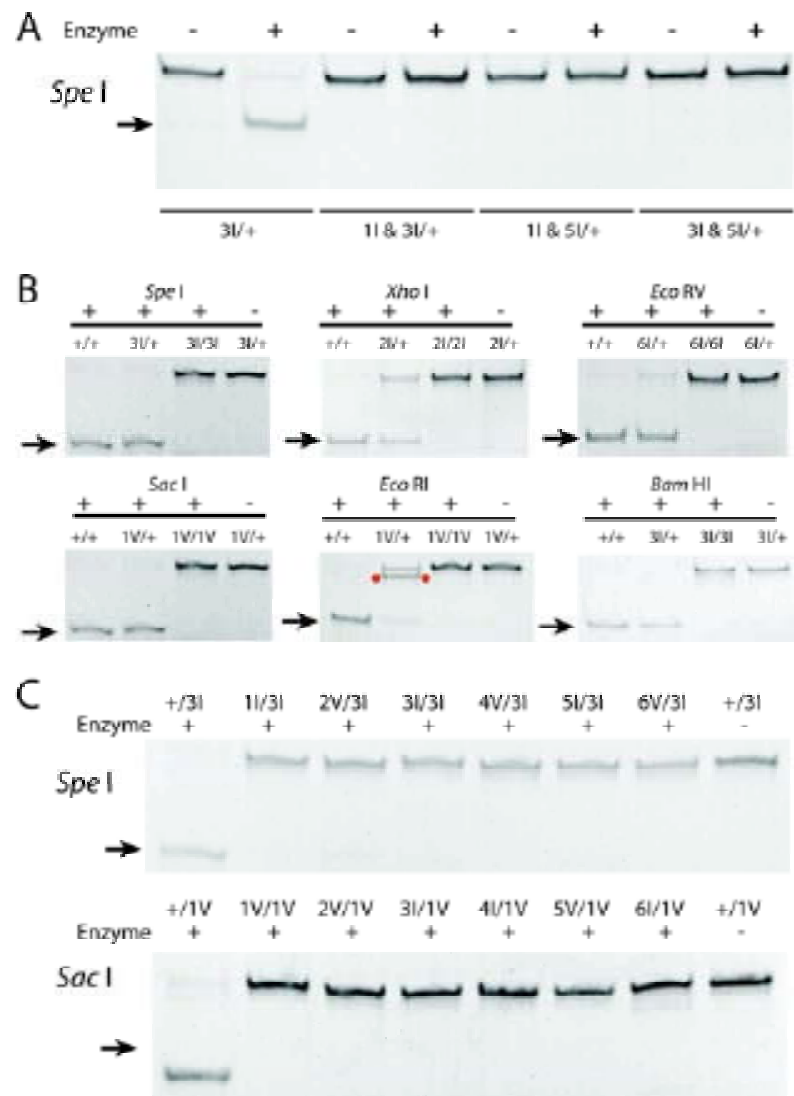

Figure 4: Double mutant non-cognate cleavage analysis. (A) Spel cleaves several single non-cognate $1 \mathrm{l} /+, 3 \mathrm{l} /+$, or $5 \mathrm{l} /+$ heteroduplex DNAs (Figure 3). Heteroduplex substrates bearing all combinations of two of these non-cognate alterations in a single strand were examined as substrates for the Spe I endonuclease and failed to produce any detectable cleavage fragments. (B) Substrates bearing the homoduplex non-cognate sequence were examined for double-strand DNA cleavage with several enzymes using the oligonucleotide assay. $+/+$ and heteroduplex substrates produced double-stranded cleavage products (Arrow). Red bullets indicate intermediate sized fragment. (C) Substrates with two non-cognate changes, one alteration on each strand of DNA, were examined as substrates for the Spel and Sacl endonuclease. The single mutation heteroduplex substrates were efficiently cleaved, as before, however, substrates lacking the cognate signal on at least a single strand failed to produce significant DNA cleavage fragments.

Several of the mispaired substrates produced an intermediate sized product in an enzyme dependent manner (Figure 3, red bullets). Control experiments with annealed oligonucleotide standards demonstrated these are consistent in size with single strand DNA cleavage. Kinetic studies with mismatched EcoRI substrates have shown a 400,000 fold range of cleavage rates between the canonical and certain non-canonical half-sites (Thielking et al., 1990), which is consistent with the apparent single strand cleavage observed for certain substrates using this oligonucleotide assay.

Double mismatch substrate analysis in cis and trans orientations

The finding that many single nucleotide mismatch substrates are susceptible to double strand DNA cleavage suggests the energetic penalties associated with the mismatch are minimal or at a minimum are often overcome under commonly used, multiple turnover, in vitro conditions. Heteroduplex DNAs with individual transition mismatches at positions 1,3 , or 5 in the Spel recognition sequence resulted substrates susceptible to cleavage using the oligonucleotide assay (Figure 3 ). Since each mismatch mutation resulted in cleavage, we asked whether any combination of the two transitions in cis would produce detectable cleavage products. As before, the $31 /+$ control reaction produced robust cleavage, however, none of the double missense substrates in cis produced significant cleavage fragments (Figure 4A). For several enzymes that produced robust cleavage of specific mismatch heteroduplex substrates, we examined substrates bearing this mismatch alteration in trans to determine their viability as substrates. In all cases the positive control reactions produced the predicted cleavage fragments, however, the double mismatch alteration in trans abrogated cleavage (Figure 4B). We examined the panel of six mutations all in trans with the Spel 31 alteration and in trans with the Sacl 1V alteration to determine whether any of these combinations resulted in a viable substrate using the oligonucleotide assay. Although the single mismatch positive controls produced robust cleavage products, none of the double mutations in trans resulted in significant cleavage (Figure $4 C)$.
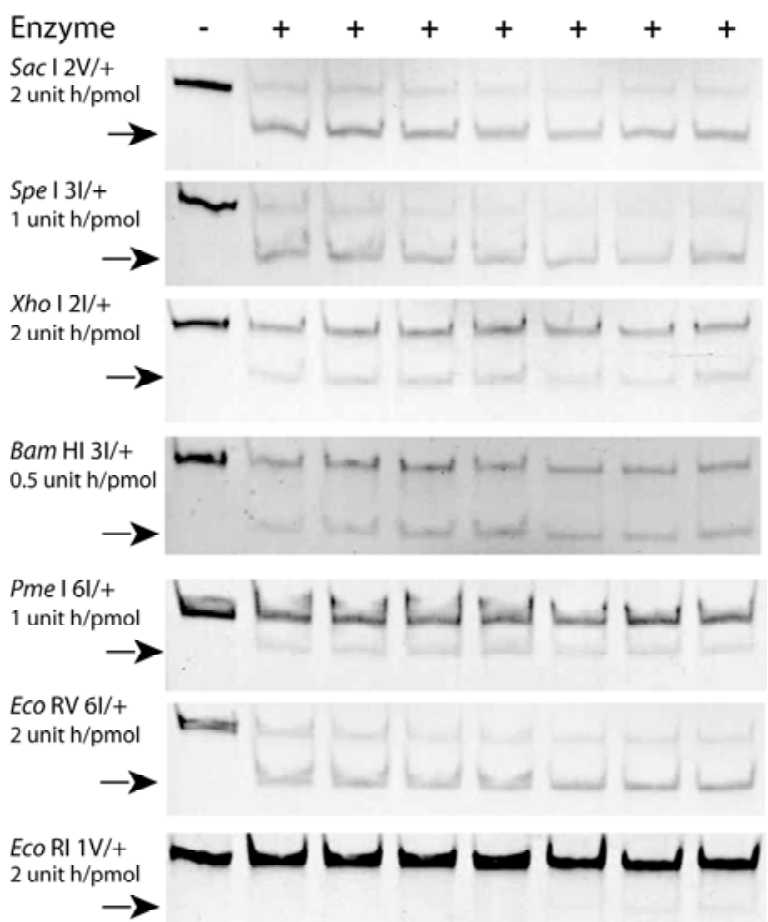

Xba $16 \mathrm{~V} /+$

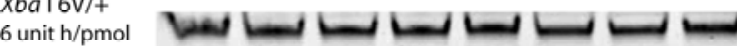

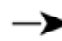

[Glycerol]

$2 \%$

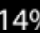

Figure 5: Effect of glycerol on heteroduplex substrate cleavage Glycerol concentrations 2-14\% were examined for the Sac I 2V/+, Spe I $3 \mathrm{l} /+$, Xho I 2l/+, Bam HI 3l/+, Pmel 6l/+, EcoRV 6l/+, EcoRI 1V/+, and $\mathrm{Xba6V/+}$ heteroduplex DNA substrates. Sacl, Spel, Xhol, BamHI, Pmel, and EcoRV efficiently produced double-stranded DNA fragments independent of glycerol concentration. Arrows indicate cleavage fragment. In contrast, EcoRI cleavage of the $1 \mathrm{~V} /+$ heteroduplex DNA was strictly glycerol dependent and Xbal cleavage of the $6 \mathrm{~V} /+$ substrate did not require high glycerol but was stimulated by glycerol. The total unit hours used per picomole of substrate is provided. 
Glycerol effect on mismatch heteroduplex cleavage.

We examined the effect of glycerol on cleavage of several single nucleotide mismatch heteroduplex DNAs. Glycerol and other water occluding chemicals can enhance cleavage of non-cognate substrate cleavage by some restriction endonucleases. Reduced specificity of some restriction enzymes under conditions of high glycerol may result from the dramatic reduction in the effective reaction volume and or by the removal of water molecules from the enzyme-substrate interface that are required for specificity. We performed our oligonucleotide assay with varying concentrations of glycerol $(2-14 \%)$ to determine whether heteroduplex DNA cleavage required or was stimulated by high glycerol concentrations. The reaction volume was increased 3 fold for these experiments and samples were taken at multiple time points, reducing the total reaction time $25-85 \%$. In all cases, the most informative partial digestion is shown (Figure 5). Only the EcoRI $5 \mathrm{I} /+$ and $1 \mathrm{~V} /+$ sites were found to require high glycerol concentration to produce detectable cleavage. The Xbal 6V/+ DNA did not require high glycerol concentration but glycerol appeared to stimulate heteroduplex DNA cleavage of this substrate. The remaining enzymes tested, including Sacl, Spel, Xhol, BamHI, Pmel and EcoRV, neither required high glycerol for heteroduplex DNA cleavage nor were detectably stimulated by glycerol for the substrate examined (Figure $5)$.

Heteroduplex cleavage is especially abundant under multiple-turnover conditions.

The prevalence of commonly used restriction enzymes that cleave heteroduplex DNA has broad implications due to their extensive use in research laboratories. This is especially true of restriction enzymes used in assays that quantify the cleavage of PCR or RT-PCR amplicons as a metric of biological phenomena. We examined in more detail the conditions required to observe efficient cleavage of mispaired heteroduplex DNA substrates. The Sacl $1 \mathrm{~V} /+$ and Spel $11 /+$ substrates were utilized and compared to cognate control substrates using oligonucleotide cleavage assays with increasing amounts of enzyme (Figure 6A). We discovered that the Sacl restriction enzyme cleaved heteroduplex mispaired DNA substrate at a lower enzyme concentrations than the cognate homoduplex substrates (Figure $6 \mathrm{~A}$ and $6 \mathrm{~B}$ ). The enzyme concentration required to achieve $50 \%$ of maximal cleavage was used to compare the substrates. The amount of Sacl required to cleave heteroduplex DNA $(0.07 \pm 0.06$ units enzyme/micL) was significantly less than that required to cleave the control DNA substrate $(0.20 \pm 0.02$ units enzyme/micL) under multiple turnover conditions (Student's t-test, $\mathrm{p}<0.0001, \mathrm{n}=3$ ). In contrast, the Spel restriction enzyme cleavage of heteroduplex DNA substrate was significantly right shifted relative to the cleavage of the cognate homoduplex control (Figure $6 \mathrm{~B})$. The enzyme concentration required to achieve $50 \%$ of maximal cleavage was dramatically and significantly increased for the Spel $11 /+$ heteroduplex $(1.05 \pm 0.02$ units enzyme/micL) over the homoduplex cognate control $\left(4.0 \times 10^{-5} \pm 7.4 \times 10^{-5}\right.$ units enzyme/micL $)$ substrate under multiple turnover conditions (Student's t-test, $p<1.0 \times 10^{-}$ $6, n=3)$.
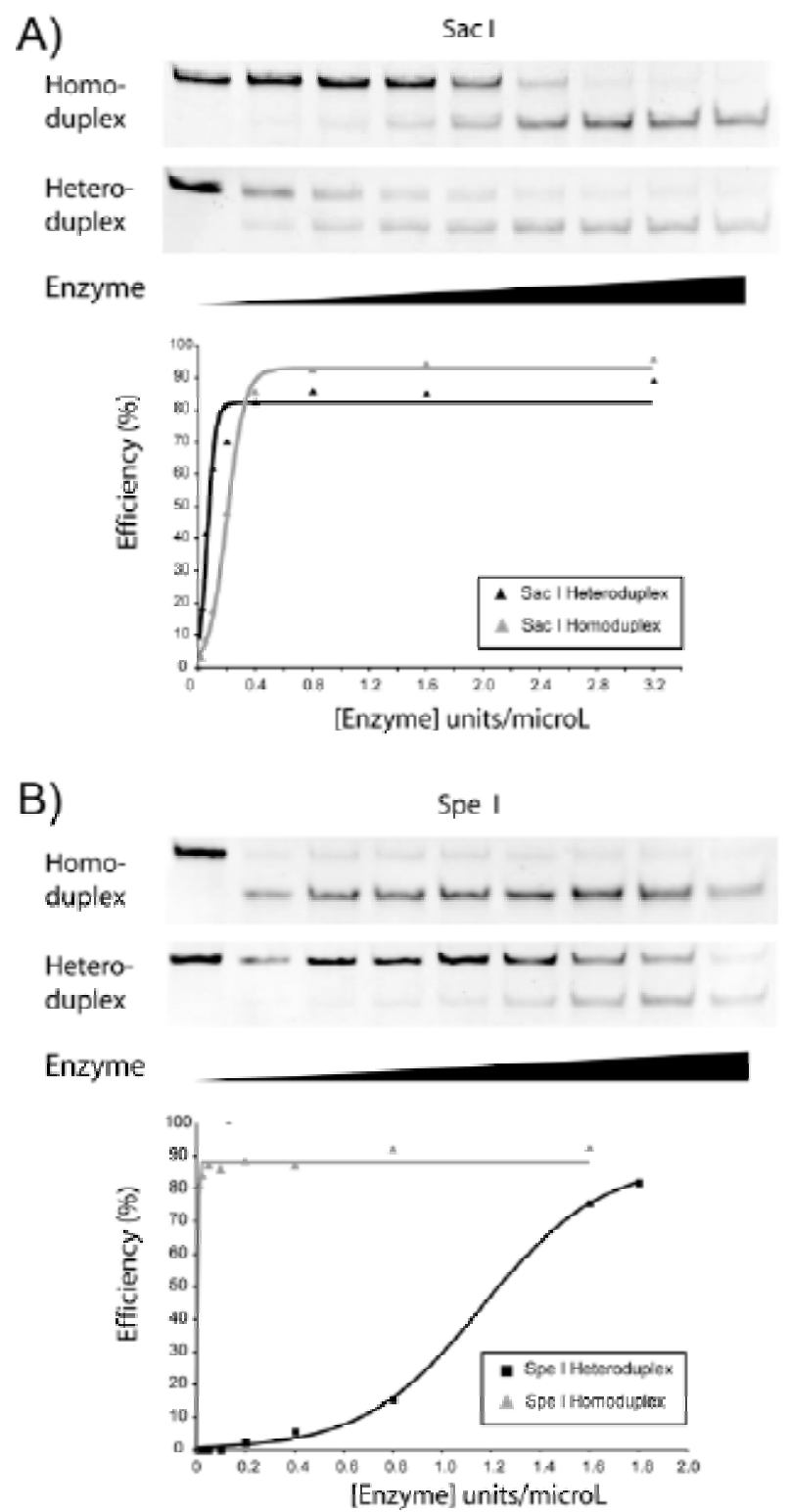

Figure 6: Enzyme concentration analysis of heteroduplex cleavage activity. Oligonucleotide DNA cleavage assays were performed with increasing units of enzyme and cognate homoduplex or heteroduplex substrate. (A) Sacl reveals robust cleavage of both heteroduplex and cognate substrates. (B) Spel reveals reduced cleavage of heteroduplex substrate, whereas, robust cleavage of the cognate substrate was observed. Cleavage efficiencies from three independent trials with each substrate were obtained. Typical results were plotted.

\section{Discussion}

Restriction endonucleases have revolutionized modern biology. The extraordinarilly high degree of specificity with which they cleave specific, well-characterized DNA sequences is paramount to their utility. In addition to their use as a tool to the molecular biologist, these enzymes have proven a valuable model system to study the nature of the protein-DNA interaction that underlies their specificity. Although detailed biophysical studies have only been performed with a few endonucleases, these and other studies have provided a foundational understanding of the energetic basis for site specificity that is key to elucidating a myriad of other essential cellular process regulated by specific protein-DNA 
interactions. Although the restriction enzyme - DNA interaction is highly specific, biophysical studies have demonstrated the basis of this specificity and its limitations. Elucidating the conditions of non-cognate cleavage has proven a valuable way to better understand specificity of protein-DNA interactions. In vitro conditions, types of non-cognate changes to the recognition sequence and flanking sequence, and site-directed mutagenesis of the enzymes that alter their specificity have been used to provide insight into this process. An interesting class of non-cognate DNA is the mispaired substrate formed from heteroduplex DNA with the cognate sequence on one strand and a single noncognate change on the other. Although mispaired heteroduplex has not been extensively studied, pioneering work with one enzyme, EcoRI, has demonstrated efficient cleavage of certain mispaired heteroduplex EcoRI sites (Thielking et al., 1990).

Mispaired heteroduplex DNA has several relevant attributes: (1) due to avid repair pathways, mispaired DNA is not common in vivo; (2) mismatched DNA is extremely prevelant in vitro, especially in procedures following PCR amplification; (3) mispaired DNA alters the normal helical structure of the molecule; (4) mispaired DNA substrates have not been the focus of study with many endonucleases; and (5) the misconception that heteroduplex DNA will not cleave or that such cleavage is a unique feature of EcoRI seems prevalent. The finding that many single nucleotide mismatch substrates remain viable for double strand DNA cleavage with many commonly-used restriction enzymes is in accord with previously published EcoRI mismatch substrate data. These data suggest that the energetic penalties associated with the non-cognate change are minimal or at least are readily overcome under commonly used multiple turnover conditions in vitro. Importantly, in cases where restriction endonuclease cleavage is used as a biological assay, reaction conditions equivalent to a several fold over-digestion, such as we have reported here, are often used to avoid the confound of incomplete digestion. These data suggest that under such conditions heteroduplex cleavage DNA is an important consideration that should not be overlooked.

Our data demonstrate that the cleavage of mispaired heteroduplex DNA is a common property observable with many commercially available restriction enzymes and is not unique to EcoRI. The fact that EcoRI is known to exhibit "star" or noncognate cleavage activity under certain in vitro conditions, notably elevated glycerol concentrations, may have contributed to the misconception that mispaired cleavage was a unique property of this enzyme. Extending our knowledge of mispaired heteroduplex cleavage to 13 additional restriction enzymes is especially relevant given the extensive use of restriction enzymes in assays and techniques following PCR. Examples of protocols where heteroduplex DNA is of concern include, but are not limited to, assays of RNA editing, recombination and mutation frequency and techniques such as site-directed mutagenesis (unique site elimination), and methods to detect spontaneous or rare mutagenic events (Deng and Nickoloff, 1992; Iland and Todd, 1992; Paschen and Djuricic, 1994; Belcher and Howe, 1997; Ling and
Robinson, 1997; Judo et al., 1998; Serth et al., 1998; Jenkins et al., 1999; Clontech Laboratories, 2001). In many cases, heteroduplex DNA is not addressed or controlled for, however, in others it is specifically stated that the heteroduplex DNA will be resistant to cleavage without data to support this assertion (Iland and Todd, 1992; Judo et al., 1998; Serth et al., 1998; Jenkins et al., 1999). When restriction endonclease cleavage data are quantified and the data are attributed to a biological phenomenon without controlling for the generation of heteroduplex or utilizing an appropriate standard curve to correct for this assumption, the data are potentially erroneous. The extent of the error in the data depends upon the amount of heteroduplex present and the efficiency of heteroduplex cleavage, which can vary wildly dependent upon the precise substrate and enzyme used. Our goal is not to dispute previously published findings and thus we did not specifically examine any of the enzymes with the precise substrates utilized by other researchers we have cited. We do believe our data adequately demonstrate that most commonly used restriction enzymes are capable of cleaving certain mispaired heteroduplex DNAs and that empirical data is required to determine whether the efficiency of substrate cleavage will interfere with a specific assay or protocol. Thus, assumptions about whether heteroduplex DNA substrates will cleave without appropriate controls to prevent their formation or inclusion in the analysis, or to appropriately standardize the data, are generally quite problematic.

\section{Materials and Methods}

PCR Assay. Forward oligonucleotide primers 24 to 36 nucleotides in length were designed to a plasmid clone (DES TOPO, Invitrogen) containing the specific enzyme recognition site or the specific enzyme recognition site with a single nucleotide substitution each with 15 5' flanking nucleotides. A reverse oligonucleotide primer was designed starting $\sim 300 \mathrm{bp}$ downstream on the plasmid. Oligonucleotides used with this assay are provided (Table 2). Oligonucleotides were synthesized by Integrated DNA technologies for this and all other experiments. PCR amplification was performed using standard methods and the resulting $\sim 315 \mathrm{bp}$ amplicons were verified on an agarose gel. After quantification with absorbance spectrometry, the PCR fragment containing the single nucleotide mutation (-) was mixed equimolar with the PCR fragment containing the restriction enzyme recognition site $(+)$. The mixture was denatured for 5 minutes at $95 \mathrm{C}$ and annealed on ice to form heteroduplex (HD) DNA. Typically a 20X restriction endonclease treatment of 1 microgram DNA (+, -, or HD) was performed per the manufacturer's instructions for each enzyme examined. For this and all other experiments, commercially purified restriction enzymes were used exclusively (New England Biolabs and Promega) in their recommended buffer at the optimal temperature. BSA was included when recommended. The reactions were separated by agarose gel electrophoresis $(2.5 \%)$, stained with ethidium bromide and densitometry was performed on sub-saturating images (NIH ImageJ). Raw intensity was corrected using base pair weighting. The assay was performed in triplicate and Chi Square tests were performed to determine if the fragment 
patterns deviated from that expected for no heteroduplex cleavage.

Oligo Assay. Forward oligonucleotides 36 nucleotides in length were designed containing the specific enzyme recognition site and the specific enzyme recognition site with a single nucleotide substitution with $\sim 10$ nucleotides flanking the site on the 5' end and $\sim 20$ nucleotides flanking on the 3 ' end. The complementary reverse oligonucleotide was designed containing the enzyme recognition site. Oligonucleotides used in this assay are provided (Table 3). Paired oligonucleotides were mixed equimolar, denatured for 5 minutes at $95 \mathrm{C}$ and annealed with cooling to $4 \mathrm{C}$ at a rate of $0.1 \mathrm{C} /$ second. Restriction endonuclease treatment of $\sim 10$ pmoles of duplex DNA (+ or HD) was performed with $25-50$ units of enzyme in a 50 microliter total volume reaction per the manufacuters' instructions. The reactions were covered with $\sim 20$ microliters mineral oil to prevent evaporation and incubated at the optimal temperature for 4 hours. $20 \%$ non-denaturing polyacrylamide gel electrophoresis (PAGE) was used to resolve $\sim 1 / 3$ of the reaction volume. Xylene cyanol and bromophenol blue were used as approximate size markers and to preserve orientation. Control experiments were performed to ensure adequate separation of unannealed oligos and double strand cleavage products. Typically, electrophoresis was performed at $150 \mathrm{~V}$ for 75 to 180 minutes. The gel was stained for 45 minutes with $0.05 \%$ ethidium bromide solution and sub-saturation images were obtained under UV light. The percentage of double-strand DNA cleavage was calculated using densitometry and NIH ImageJ. Raw intensity was corrected using base pair weighting. Greater than 5\% heteroduplex DNA cleavage was deemed significant. The glycerol concentration assay used the standard oligo assay with the following exceptions: a 150 microliter reaction volume was used, varying glycerol concentration of $2-14 \%$ was used, the reaction was incubated for 3 hours, the glycerol concentration of $1 / 3$ of the reaction was adjusted to $6 \%$ with cold water or $33 \%$ glycerol, and samples were concentrated to reduce their volume, as needed.

\section{Funding and Acknowledgments}

We thank the American Society for Pharmacology and Experimental Therapeutics (ASPET) summer undergraduate research fellowship (SURF) award (to M.T.L.), American Heart Association award (0630344N to M.J.P.), National Institutes of Health grant (AG025046 to M.J.P.) and the University of Pittsburgh Department of Pharmacology and School of Medicine for financial support. We also thank Dr. Linda Jen-Jacobson for critical advice revising the manuscript, Emily Trostel for editorial comments and Dr. Alicia Celotto for suggestions and technical advice.

Table 2: Oligonucleotides used in the PCR heteroduplex assay. PCR primers are designated forward (end in F) or reverse (end in R). Restriction recognition sites are underlined and correspond to the known site $(+)$ or a mutated site $(-)$. The mutation position in the recognition site (\#) and the type of mutation, transversion (V) or transition (I) are shown.

\begin{tabular}{lll}
\hline Enzyme & Name & Oligonucleotide Sequence \\
\hline $\begin{array}{l}\text { Ahdl } \\
\text { Ahdl }\end{array}$ & AhdIPCRR & ATG AAG CCA TAC CAA ACG ACG AGC \\
Ahdl & Ahdl+PCRF & CGT TCA TCC ATA GTT GCC TGA CTC CCC GTC GTG TAG \\
AlwNI & AlwNIPCRR & AAA CCC GAC AGG ACT ATA AAG ATA \\
AlwNI & AlwNI+PCRF & GCT CTG CTA ATC CTG TTA CCA GTG GCT GCT G \\
AlwNI & AlwNI-PCR(\#1V)F & GCT CTG CTA ATC CTG TTA CAA GTG GCT GCT G \\
Eco0109I & Eco0PCRR & TTA CTT TCA CCA GCG TTT CTG GGT \\
Eco0109I & Eco0+PCRF & ATC ACC GAA ACG CGC GAA CGA AAG GGC CTC GTG ATA CGC CT \\
Eco0109I & Eco0-PCR(\#3I)F & ATC ACC GAA ACG CGC GAA CGA A AG AGC CTC GTG ATA CGC CT \\
Pmel & PmelPCRR & TAC GCC AAG CTT GCA TGC CTG CAG GTC GAC TGA TCA \\
$P m e l$ & Pmel+PCRF & TAT GAG CTC CTC ATT GAT TAA GTT TAA ACC CGC T \\
Pmel & Pmel-PCR(\#5V)F & TAT GAG CTC CTC ATT GAT TAA GTT TCA ACC CGC T \\
\hline
\end{tabular}

Table 3: Oligonucleotides used in the Oligonucleotide heteroduplex assay. Oligonucleotides are designated top (end in T) or bottom (end in B). Restriction recognition sites are underlined and correspond to the known site $(+)$ or a mutated site $(-)$. The mutation position in the recognition site (\#) and the type of mutation, transversion (V) or transition (I) are shown.

\begin{tabular}{|c|c|c|}
\hline Enzyme & Name & Oligonucleotide Sequence \\
\hline Ahdl & Ahdl+T & $\begin{array}{l}\text { TTG CAG CAC TGG GGC CAG ATG GTA AGC CCT CCC GTA TCG TAG TTA- } \\
\text { TCT ACA CGA CGG GGA GTC AGG CAA CTA TGG ATG AAC GAA ATA GAC }\end{array}$ \\
\hline Ahdl & Ahdl+B & $\begin{array}{l}\text { GTC TAT TTC GTT CAT CCA TAG TTG CCT GAC TCC CCG TCG TGT AGA- } \\
\text { TAA CTA CGA TAC GGG AGG GCT TAC CAT CTG GCC CCA GTG CTG CAA }\end{array}$ \\
\hline Ahdl & Ahdl-(\#1I)B & $\begin{array}{l}\text { GTC TAT TTC GTT CAT CCA TAG TTG CCT AAC TCC CCG TCG TGT AGA- } \\
\text { TAA CTA CGA TAC GGG AGG GCT TAC CAT CTG GCC CCA GTG CTG CAA }\end{array}$ \\
\hline Ahdl & Ahdl-(\#1V)B & $\begin{array}{l}\text { GTC TAT TTC GTT CAT CCA TAG TTG CCT TAC TCC CCG TCG TGT AGA- } \\
\text { TAA CTA CGA TAC GGG AGG GCT TAC CAT CTG GCC CCA GTG CTG CAA }\end{array}$ \\
\hline BamHI & $\mathrm{BamHI+T}$ & GCG CGA AAT GGT CAC CGG GTG GAT CCC TTT CCG GGA \\
\hline BamHI & BamHI-(\#6V)T & GCG CGA AAT GGT CAC CGG GTG GAT CGC TTT CCG GGA \\
\hline BamHI & $\mathrm{BamHI}+\mathrm{B}$ & TCC CGG AAA GGG ATC CAC CCG GTG ACC ATT TCG CGC \\
\hline $\mathrm{BamHI}$ & BamHI-(\#5V)B & TCC CGG AAA GGG ATA CAC CCG GTG ACC ATT TCG CGC \\
\hline $\mathrm{BamHI}$ & BamHI-(\#5I)B & TCC CGG AAA GGG ATT CAC CCG GTG ACC ATT TCG CGC \\
\hline $\mathrm{BamHI}$ & BamHI-(\#1I)B & TCC CGG AAA GAG ATC CAC CCG GTG ACC ATT TCG CGC \\
\hline BamHI & BamHI-(\#2V)B & TCC CGG AAA GGC ATC CAC CCG GTG ACC ATT TCG CGC \\
\hline
\end{tabular}


10 Langhans and Palladino

Table 3 (continued): Oligonucleotides used in the Oligonucleotide heteroduplex assay.

\begin{tabular}{|c|c|c|}
\hline Enzyme & Name & Oligonucleotide Sequence \\
\hline BamHI & BamHI-(\#3I)B & TCC CGG AAA GGG GTC CAC CCG GTG ACC ATT TCG CGC \\
\hline BamHI & BamHI-(\#4V)B & TCC CGG AAA GGG AGC CAC CCG GTG ACC ATT TCG CGC \\
\hline $\mathrm{BamHI}$ & BamHI-(\#6V)B & TCC CGG AAA GGG ATC GAC CCG GTG ACC ATT TCG CGC \\
\hline Eco0109l & Eco0+T & AGG CGT ATC ACG AGG CCC TTT CGT TCG CGC GTT TCG GTG AT \\
\hline Eco0109l & Eco0+B & ATC ACC GAA ACG $\overline{C G C ~ G A A ~ C G A ~ A A G ~ G G C ~ C T C ~ G T G ~ A T A ~ C G C ~ C T ~}$ \\
\hline Eco0109l & Eco0-(\#3I)B & ATC ACC GAA ACG CGC GAA CGA AAG AGC CTC GTG ATA CGC CT \\
\hline Eco0109l & $\mathrm{EcoO}-(\# 3 \mathrm{~V}) \mathrm{B}$ & ATC ACC GAA ACG CGC GAA CGA AAG CGC CTC GTG ATA CGC CT \\
\hline EcoRI & EcoRl+T & GCG CGA AAT GGT CAC CGG GTG AAT TCC TTT CCG GGA \\
\hline EcoRI & EcoRI-(\#1V)T & GCG CGA AAT GGT CAC CGG GTT AAT TCC TTT CCG GGA \\
\hline EcoRI & EcoRI+B & TCC CGG AAA GGA ATT CAC CCG GTG ACC ATT TCG CGC \\
\hline EcoRI & EcoRI-(\#1V)B & TCC CGG AAA GTA ATT CAC CCG GTG ACC ATT TCG CGC \\
\hline EcoRI & EcoRI-(\#2I)B & TCC CGG AAA GGG ATT CAC CCG GTG ACC ATT TCG CGC \\
\hline EcoRI & EcoRI-(\#3V)B & TCC CGG AAA GGA TTT CAC CCG GTG ACC ATT TCG CGC \\
\hline EcoRI & EcoRI-(\#4I)B & TCC CGG AAA GGA ACT CAC CCG GTG ACC ATT TCG CGC \\
\hline EcoRI & EcoRI-(\#5V)B & TCC CGG AAA GGA ATG CAC CCG GTG ACC ATT TCG CGC \\
\hline EcoRI & EcoRI-(\#5I)B & TCC CGG AAA GGA ATC CAC CCG GTG ACC ATT TCG CGC \\
\hline EcoRI & EcoRl-(\#6I)B & TCC CGG AAA GGA ATT TAC CCG GTG ACC ATT TCG CGC \\
\hline EcoRV & EcoRV+T & GCG CGA AAT GGT CAC CGG GTG ATA TCC TTT CCG GGA \\
\hline EcoRV & EcoRV-(\#6I)T & GCG CGA AAT GGT CAC CGG GTG ATA TTC TTT CCG GGA \\
\hline EcoRV & EcoRV+B & TCC CGG AAA GGA TAT CAC CCG GTG ACC ATT TCG CGC \\
\hline EcoRV & EcoRV-(\#1V)B & TCC CGG AAA GTA TAT CAC CCG GTG ACC ATT TCG CGC \\
\hline EcoRV & EcoRV-(\#2I)B & TCC CGG AAA GGG TAT CAC CCG GTG ACC ATT TCG CGC \\
\hline EcoRV & EcoRV-(\#3I)B & TCC CGG AAA G $\overline{G A}$ CAT CAC CCG GTG ACC ATT TCG CGC \\
\hline EcoRV & EcoRV-(\#3V)B & TCC CGG AAA GGA GAT CAC CCG GTG ACC ATT TCG CGC \\
\hline EcoRV & EcoRV-(\#4I)B & TCC CGG AAA G $\overline{G A}$ TGT CAC CCG GTG ACC ATT TCG CGC \\
\hline EcoRV & EcoRV-(\#5V)B & TCC CGG AAA GGA TAG CAC CCG GTG ACC ATT TCG CGC \\
\hline EcoRV & EcoRV-(\#6I)B & 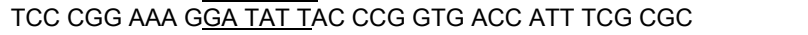 \\
\hline HindIII & Hind $3+T$ & GCG CGA AAT GGT CAC CGG GTA AGC TTC TTT CCG GGA \\
\hline HindllI & Hind3+B & TCC CGG AAA GAA GCT TAC CCG GTG ACC ATT TCG CGC \\
\hline HindllI & Hind3-(\#2V)B & TCC CGG AAA GAC GCT TAC CCG GTG ACC ATT TCG CGC \\
\hline Hindlll & Hind3-(\#2I)B & TCC CGG AAA GAG GCT TAC CCG GTG ACC ATT TCG CGC \\
\hline HindllI & Hind3-(\#11)B & 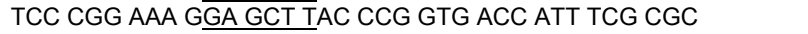 \\
\hline Hindlll & Hind3-(\#3I)B & TCC CGG AAA GAA ACT TAC CCG GTG ACC ATT TCG CGC \\
\hline Hindlll & Hind3-(\#4V)B & TCC CGG AAA GAA GAT TAC CCG GTG ACC ATT TCG CGC \\
\hline Hindlll & Hind3-(\#5I)B & TCC CGG AAA GAA GCC TAC CCG GTG ACC ATT TCG CGC \\
\hline HindIII & Hind3-(\#6V)B & TCC CGG AAA GAA GCT GAC CCG GTG ACC ATT TCG CGC \\
\hline Pmel & Pmel+T & GCT GAT CAG CGG GTT TAA ACT TAA TCA ATG AGG AGC TCA TA \\
\hline Pmel & Pmel-(\#6I)T & AGC GGG TTT AGA CTT AAT CAA TGA GGA GCT CAT A \\
\hline Pmel & Pmel+B & TAT GAG CTC CTC ATT GAT TAA GTT TAA ACC CGC T \\
\hline Pmel & Pmel-(\#6l)B & TAT GAG CTC CTC ATT GAT TAA GTT TAG ACC CGC T \\
\hline Pmel & Pmel-(\#5V)B & TAT GAG CTC CTC ATT GAT TAA GTT TCA ACC CGC T \\
\hline Pmel & Pmel-(\#5I)B & TAT GAG CTC CTC ATT GAT TAA GTT TGA ACC CGC T \\
\hline Pstl & Pstl+T & GCG CGA AAT GGT CAC CGG GTC TGC AGC TTT CCG GGA \\
\hline Pstl & Pstl+B & TCC CGG AAA GCT GCA GAC CCG GTG ACC ATT TCG CGC \\
\hline Pstl & Pstl-(\#3V) & TCC CGG AAA GCT TCA GAC CCG GTG ACC ATT TCG CGC \\
\hline Pstl & Pstl-(\#3I) & TCC CGG AAA GCT ACA GAC CCG GTG ACC ATT TCG CGC \\
\hline Sacl & $\mathrm{Sacl}+\mathrm{T}$ & GCG CGA AAT GGT CAC CGG GTG AGC TCC TTT CCG GGA \\
\hline Sacl & Sacl-(\#1V)T & GCG CGA AAT GGT CAC CGG GT T AGC TCC TTT CCG GGA \\
\hline Sacl & $\mathrm{Sacl}+\mathrm{B}$ & TCC CGG AAA GGA GCT CAC CCG GTG ACC ATT TCG CGC \\
\hline Sacl & Sacl-(\#1V)B & TCC CGG AAA GTA GCT CAC CCG GTG ACC ATT TCG CGC \\
\hline Sacl & Sacl-(\#2V)B & TCC CGG AAA GGC GCT CAC CCG GTG ACC ATT TCG CGC \\
\hline Sacl & Sacl-(\#3I)B & TCC CGG AAA GGA ACT CAC CCG GTG ACC ATT TCG CGC \\
\hline Sacl & Sacl-(\#4I)B & TCC CGG AAA GGA GTT CAC CCG GTG ACC ATT TCG CGC \\
\hline Sacl & Sacl-(\#5V)B & TCC CGG AAA GGA GCA CAC CCG GTG ACC ATT TCG CGC \\
\hline Sacl & Sacl-(\#6I)B & TCC CGG AAA GGA GCT TAC CCG GTG ACC ATT TCG CGC \\
\hline Sall & Sall+T & GCG CGA AAT GGT CAC CGG GTG TCG ACC TTT CCG GGA \\
\hline Sall & Sall+B & TCC CGG AAA GGT CGA CAC CCG GTG ACC ATT TCG CGC \\
\hline Sall & Sall-(\#2I)B & TCC CGG AAA GGC CGA CAC CCG GTG ACC ATT TCG CGC \\
\hline Sall & Sall-(\#2V)B & TCC CGG AAA GGG CGA CAC CCG GTG ACC ATT TCG CGC \\
\hline Spel & Spel+T & GCG CGA AAT GGT CAC CGG GTA CTA GTC TTT CCG GGA \\
\hline Spel & Spel-(\#3I)T & GCG CGA AAT GGT CAC CGG GTA CCA GTC TTT CCG GGA \\
\hline Spel & Spel+B & TCC CGG AAA GAC TAG TAC CCG GTG ACC ATT TCG CGC \\
\hline Spel & Spel-(\#1I)B & TCC CGG AAA GGC TAG TAC CCG GTG ACC ATT TCG CGC \\
\hline Spel & Spel-(\#2V)B & TCC CGG AAA GAA TAG TAC CCG GTG ACC ATT TCG CGC \\
\hline Spel & Spel-(\#3I)B & TCC CGG AAA GAC CAG TAC CCG GTG ACC ATT TCG CGC \\
\hline Spel & Spel-(\#4V)B & TCC CGG AAA GAC TTG TAC CCG GTG ACC ATT TCG CGC \\
\hline Spel & Spel-(\#5I)B & TCC CGG AAA GAC TAA TAC CCG GTG ACC ATT TCG CGC \\
\hline Spel & Spel-(\#6V)B & TCC CGG AAA GAC TAG AAC CCG GTG ACC ATT TCG CGC \\
\hline Spel & Spel-(\#1|3|)B & TCC CGG AAA GGC CAG TAC CCG GTG ACC ATT TCG CGC \\
\hline Spel & Spel-(\#1|5I)B & TCC CGG AAA GGC TAA TAC CCG GTG ACC ATT TCG CGC \\
\hline Spel & Spel-(\#3|5I)B & TCC CGG AAA GAC CAA TAC CCG GTG ACC ATT TCG CGC \\
\hline
\end{tabular}


Table 3 (continued): Oligonucleotides used in the Oligonucleotide heteroduplex assay.

\begin{tabular}{lll}
\hline Enzyme & Name & Oligonucleotide Sequence \\
\hline Xbal & Xbal+T & GCG CGA AAT GGT CAC CGG GTT CTA GAC TTT CCG GGA \\
Xbal & Xbal-(6V)T & GCG CGA AAT GGT CAC CGG GTT CTA GCC TTT CCG GGA \\
Xbal & Xbal+B & TCC CGG AAA GTC TAG AAC CCG GTG ACC ATT TCG CGC \\
Xbal & Xbal-(\#2I)B & TCC CGG AAA GTT TAG AAC CCG GTG ACC ATT TCG CGC \\
Xbal & Xbal-(\#2V)B & TCC CGG AAA GTG TAG AAC CCG GTG ACC ATT TCG CGC \\
Xbal & Xbal-(\#1)B & TCC CGG AAA GCC TAG AAC CCG GTG ACC ATT TCG CGC \\
Xbal & Xbal-(\#3I)B & TCC CGG AAA GTC CAG AAC CCG GTG ACC ATT TCG CGC \\
Xbal & Xbal-(\#4V)B & TCC CGG AAA GTC TCG AAC CCG GTG ACC ATT TCG CGC \\
Xbal & Xbal-(\#5I)B & TCC CGG AAA GTC TAA AAC CCG GTG ACC ATT TCG CGC \\
Xbal & Xbal-(\#6V)B & TCC CGG AAA GTC TAG CAC CCG GTG ACC ATT TCG CGC \\
& & \\
Xhol & Xhol+T & GCG CGA AAT GGT CAC CGG GTC TCG AGC TTT CCG GGA \\
Xhol & Xhol-(\#2I)T & GCG CGA AAT GGT CAC CGG GTC CCG AGC TTT CCG GGA \\
Xhol & Xhol+B & TCC CGG AAA GCT CGA GAC CCG GTG ACC ATT TCG CGC \\
Xhol & Xhol-(\#1V)B & TCC CGG AAA GAT CGA GAC CCG GTG ACC ATT TCG CGC \\
Xhol & Xhol-(\#2I)B & TCC CGG AAA GCC CGA GAC CCG GTG ACC ATT TCG CGC \\
Xhol & Xhol-(\#3V)B & TCC CGG AAA GCT AGA GAC CCG GTG ACC ATT TCG CGC \\
Xhol & Xhol-(\#4I)B & TCC CGG AAA GCT CAA GAC CCG GTG ACC ATT TCG CGC \\
Xhol & Xhol-(\#5V)B & TCC CGG AAA GCT CGC GAC CCG GTG ACC ATT TCG CGC \\
Xhol & Xhol-(\#6I)B & TCC CGG AAA GCT CGA AAC CCG GTG ACC ATT TCG CGC \\
Xhol & Xhol-(\#6V)B & TCC CGG AAA GCT CGA CAC CCG GTG ACC ATT TCG CGC \\
\end{tabular}

Notes: $A$ hdl has an 11 nucleotide recognition site and required longer oligomers to assay cleavage. Pmel+T without the 7 nucleotide overhang gave similar results.

\section{References}

Alves, J., Pingoud, A., Haupt, W., Langowski, J., Peters, F., Maass, G., and Wolff, C. (1984). The influence of sequences adjacent to the recognition site on the cleavage of oligodeoxynucleotides by the EcoRI endonuclease. Eur J Biochem 140, 83-92.

Alves, J., Pingoud, A., Langowski, J., Urbanke, C., and Maass, G. (1982). Two identical subunits of the EcoRI restriction endonuclease Co-operate in the binding and cleavage of the palindromic substrate. Eur $\mathrm{J}$ Biochem 124, 139-42.

Becker, M. M., Lesser, D., Kurpiewski, M., Baranger, A., and Jen-Jacobson, L. (1988). "Ultraviolet footprinting" accurately maps sequence-specific contacts and DNA kinking in the EcoRI endonuclease-DNA complex. Proc Natl Acad Sci U S A 85, 6247-51.

Belcher, S. M., and Howe, J. R. (1997). Characterization of RNA editing of the glutamate-receptor subunits GluR5 and GluR6 in granule cells during cerebellar development. Brain Res Mol Brain Res 52, 130-8.

Bickle, T. A., and Kruger, D. H. (1993). Biology of DNA restriction. Microbiol Rev 57, 434-50.

Clontech Laboratories, I. (2001). Transformer (TM) sitedirected mutagenesis kit user manual.

Deng, W. P., and Nickoloff, J. A. (1992). Site-directed mutagenesis of virtually any plasmid by eliminating a unique site. Anal Biochem 200, 81-8.

Engler, L. E., Sapienza, P., Dorner, L. F., Kucera, R., Schildkraut, I., and Jen-Jacobson, L. (2001). The energetics of the interaction of $\mathrm{BamHI}$ endonuclease with its recognition site GGATCC. J Mol Biol 307, 61936.

Engler, L. E., Welch, K. K., and Jen-Jacobson, L. (1997). Specific binding by EcoRV endonuclease to its DNA recognition site GATATC. J Mol Biol 269, 82-101.

Golz, S., Birkenkamp-Demtroder, K., and Kemper, B. (1998a). Enzymatic mutation detection. Procedure for screening and mapping of mutations by immobilised endonuclease VII. Nucleic Acids Res 26, 1132-3.

Golz, S., Greger, B., and Kemper, B. (1998b). Enzymatic mutation detection. Phosphate ions increase incision efficiency of endonuclease VII at a variety of damage sites in DNA. Mutat Res 382, 85-92.

Hiller, D. A., Rodriguez, A. M., and Perona, J. J. (2005). Non-cognate enzyme-DNA complex: structural and kinetic analysis of EcoRV endonuclease bound to the EcoRI recognition site GAATTC. J Mol Biol 354, 12136.

Horton, N. C., Otey, C., Lusetti, S., Sam, M. D., Kohn, J., Martin, A. M., Ananthnarayan, V., and Perona, J. J. (2002). Electrostatic contributions to site specific DNA cleavage by EcoRV endonuclease. Biochemistry 41, 10754-63.

Horton, N. C., and Perona, J. J. (1998a). Recognition of flanking DNA sequences by EcoRV endonuclease involves alternative patterns of water-mediated contacts. J Biol Chem 273, 21721-9.

Horton, N. C., and Perona, J. J. (1998b). Role of proteininduced bending in the specificity of DNA recognition: crystal structure of EcoRV endonuclease complexed with d(AAAGAT) + d(ATCTT). J Mol Biol 277, 779-87.

Iland, H. J., and Todd, A. V. (1992). Estimation of the proportions of mutant and normal $\mathrm{N}$-ras alleles by allele specific restriction analysis. Nucleic Acids Res 20, 620.

Jen-Jacobson, L. (1997). Protein-DNA recognition complexes: conservation of structure and binding energy in the transition state. Biopolymers 44, 153-80.

Jen-Jacobson, L., Engler, L. E., and Jacobson, L. A. (2000). Structural and thermodynamic strategies for site-specific DNA binding proteins. Structure 8, 101523.

Jen-Jacobson, L., L. E. Engler, J. T. Ames, M. R. Kurpiewski and A. Grigorescu (2000). Thermodynamic Parameters of Specific and Nonspecific Protein-DNA Binding. Supramol Chem 12, 142-60.

Jenkins, G. J., Suzen, H. S., Sueiro, R. A., and Parry, J. M. (1999). The restriction site mutation assay: a review of the methodology development and the current status of the technique. Mutagenesis 14, 439-48.

Judo, M. S., Wedel, A. B., and Wilson, C. (1998). Stimulation and suppression of PCR-mediated recombination. Nucleic Acids Res 26, 1819-25. 
Kovall, R. A., and Matthews, B. W. (1999). Type II restriction endonucleases: structural, functional and evolutionary relationships. Curr Opin Chem Biol 3, 57883.

Kurpiewski, M. R., Engler, L. E., Wozniak, L. A., Kobylanska, A., Koziolkiewicz, M., Stec, W. J., and JenJacobson, L. (2004). Mechanisms of coupling between DNA recognition specificity and catalysis in EcoRI endonuclease. Structure 12, 1775-88.

Lesser, D. R., Kurpiewski, M. R., and Jen-Jacobson, L. (1990). The energetic basis of specificity in the Eco RI endonuclease--DNA interaction. Science 250, 776-86.

Lesser, D. R., Kurpiewski, M. R., Waters, T., Connolly, B. A., and Jen-Jacobson, L. (1993). Facilitated distortion of the DNA site enhances EcoRI endonuclease-DNA recognition. Proc Natl Acad Sci U S A 90, 7548-52.

Ling, M. M., and Robinson, B. H. (1997). Approaches to DNA mutagenesis: an overview. Anal Biochem 254, 157-78.

Martin, A. M., Sam, M. D., Reich, N. O., and Perona, J. J. (1999). Structural and energetic origins of indirect readout in site-specific DNA cleavage by a restriction endonuclease. Nat Struct Biol 6, 269-77.

Modrich, P. (1995). Mismatch repair, genetic stability and tumour avoidance. Philos Trans R Soc Lond B Biol Sci 347, 89-95.

Niv, M. Y., Ripoll, D. R., Vila, J. A., Liwo, A., Vanamee, E. S., Aggarwal, A. K., Weinstein, H., and Scheraga, H. A. (2007). Topology of Type II REases revisited; structural classes and the common conserved core. Nucleic Acids Res 35, 2227-37.

Parry, D., Moon, S. A., Liu, H. H., Heslop, P., and Connolly, B. A. (2003). DNA recognition by the EcoRV restriction endonuclease probed using base analogues. J Mol Biol 331, 1005-16.

Paschen, W., and Djuricic, B. (1994). Extent of RNA editing of glutamate receptor subunit GluR5 in different brain regions of the rat. Cell Mol Neurobiol 14, 259-70.

Perona, J. J. (2002). Type II restriction endonucleases. Methods 28, 353-64.

Pingoud, A., Alves, J., and Geiger, R. (1993). Restriction Enzymes. In Enzymes in Molecular Biology, M. M. Burrell, ed. (Totowa, Humana Press), pp. 107-200.

Pingoud, A., Fuxreiter, M., Pingoud, V., and Wende, W. (2005). Type II restriction endonucleases: structure and mechanism. Cell Mol Life Sci 62, 685-707.

Pingoud, A., and Jeltsch, A. (2001). Structure and function of type II restriction endonucleases. Nucleic Acids Res 29, 3705-27.

Roberts, R. J. (2005). How restriction enzymes became the workhorses of molecular biology. Proc Natl Acad Sci U S A 102, 5905-8.

Roberts, R. J., Vincze, T., Posfai, J., and Macelis, D. (2007). REBASE--enzymes and genes for DNA restriction and modification. Nucleic Acids Res 35, D269-70.
Sam, M. D., Horton, N. C., Nissan, T. A., and Perona, J. J. (2001). Catalytic efficiency and sequence selectivity of a restriction endonuclease modulated by a distal manganese ion binding site. J Mol Biol 306, 851-61.

Sapienza, P. J., Dela Torre, C. A., McCoy, W. H. t., Jana, S. V., and Jen-Jacobson, L. (2005). Thermodynamic and kinetic basis for the relaxed DNA sequence specificity of "promiscuous" mutant EcoRI endonucleases. J Mol Biol 348, 307-24.

Sapienza, P. J., Rosenberg, J. M., and Jen-Jacobson, L. (2007). Structural and thermodynamic basis for enhanced DNA binding by a promiscuous mutant EcoRI endonuclease. Structure 15, 1368-82.

Serth, J., Panitz, F., Herrmann, H., and Alves, J. (1998). Single-tube nested competitive PCR with homologous competitor for quantitation of DNA target sequences: theoretical description of heteroduplex formation, evaluation of sensitivity, precision and linear range of the method. Nucleic Acids Res 26, 4401-8.

Thielking, V., Alves, J., Fliess, A., Maass, G., and Pingoud, A. (1990). Accuracy of the EcoRI restriction endonuclease: binding and cleavage studies with oligodeoxynucleotide substrates containing degenerate recognition sequences. Biochemistry 29, 4682-91.

Thielking, V., Selent, U., Kohler, E., Landgraf, A., Wolfes, H., Alves, J., and Pingoud, A. (1992). Mg2+ confers DNA binding specificity to the EcoRV restriction endonuclease. Biochemistry 31, 3727-32.

Vermote, C. L., and Halford, S. E. (1992). EcoRV restriction endonuclease: communication between catalytic metal ions and DNA recognition. Biochemistry 31, 6082-9.

Vipond, I. B., and Halford, S. E. (1995). Specific DNA recognition by EcoRV restriction endonuclease induced by calcium ions. Biochemistry 34, 1113-9.

Watrob, H., Liu, W., Chen, Y., Bartlett, S. G., JenJacobson, L., and Barkley, M. D. (2001). Solution conformation of EcoRI restriction endonuclease changes upon binding of cognate DNA and $\mathrm{Mg} 2+$ cofactor. Biochemistry 40, 683-92.

Wenz, C., Jeltsch, A., and Pingoud, A. (1996). Probing the indirect readout of the restriction enzyme EcoRV. Mutational analysis of contacts to the DNA backbone. $\mathrm{J}$ Biol Chem 271, 5565-73.

Winkler, F. K., Banner, D. W., Oefner, C., Tsernoglou, D., Brown, R. S., Heathman, S. P., Bryan, R. K., Martin, P. D., Petratos, K., and Wilson, K. S. (1993). The crystal structure of EcoRV endonuclease and of its complexes with cognate and non-cognate DNA fragments. Embo J 12, 1781-95.

Wolfes, H., Fliess, A., and Pingoud, A. (1985). A comparison of the structural requirements for DNA cleavage by the isoschizomers Haell, BspRI and BsuRI. Eur J Biochem 150, 105-10. 


\section{Further Reading}

Caister Academic Press is a leading academic publisher of advanced texts in microbiology, molecular biology and medical research. Full details of all our publications at caister.com

- MALDI-TOF Mass Spectrometry in Microbiology Edited by: M Kostrzewa, S Schubert (2016) www.caister.com/malditof

- Aspergillus and Penicillium in the Post-genomic Era Edited by: RP Vries, IB Gelber, MR Andersen (2016) www.caister.com/aspergillus2

- The Bacteriocins: Current Knowledge and Future Prospects Edited by: RL Dorit, SM Roy, MA Riley (2016)

www.caister.com/bacteriocins

- Omics in Plant Disease Resistance Edited by: V Bhadauria (2016) www.caister.com/opd

- Acidophiles: Life in Extremely Acidic Environments Edited by: R Quatrini, DB Johnson (2016) www.caister.com/acidophiles

- Climate Change and Microbial Ecology: Current Research and Future Trend

Edited by: J Marxsen (2016)

www.caister.com/climate

- Biofilms in Bioremediation: Current Research and Emerging Technologies

Edited by: G Lear (2016)

www.caister.com/biorem

- Microalgae: Current Research and Applications Edited by: MN Tsaloglou (2016) www.caister.com/microalgae

- Gas Plasma Sterilization in Microbiology: Theory, Applications, Pitfalls and New Perspectives Edited by: H Shintani, A Sakudo (2016) www.caister.com/gasplasma

- Virus Evolution: Current Research and Future Directions Edited by: SC Weaver, M Denison, M Roossinck, et al. (2016) www.caister.com/virusevol

- Arboviruses: Molecular Biology, Evolution and Control Edited by: N Vasilakis, DJ Gubler (2016) www.caister.com/arbo

- Shigella: Molecular and Cellular Biology Edited by: WD Picking, WL Picking (2016) www.caister.com/shigella

-Aquatic Biofilms: Ecology, Water Quality and Wastewater Treatment

Edited by: AM Romaní, H Guasch, MD Balaguer (2016)

www.caister.com/aquaticbiofilms

- Alphaviruses: Current Biology

Edited by: S Mahalingam, L Herrero, B Herring (2016)

www.caister.com/alpha

- Thermophilic Microorganisms

Edited by: F Li (2015)

www.caister.com/thermophile
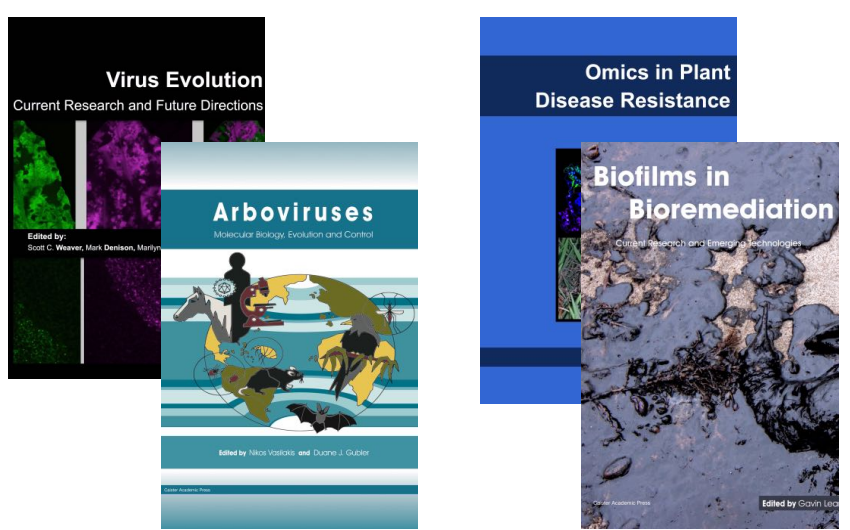
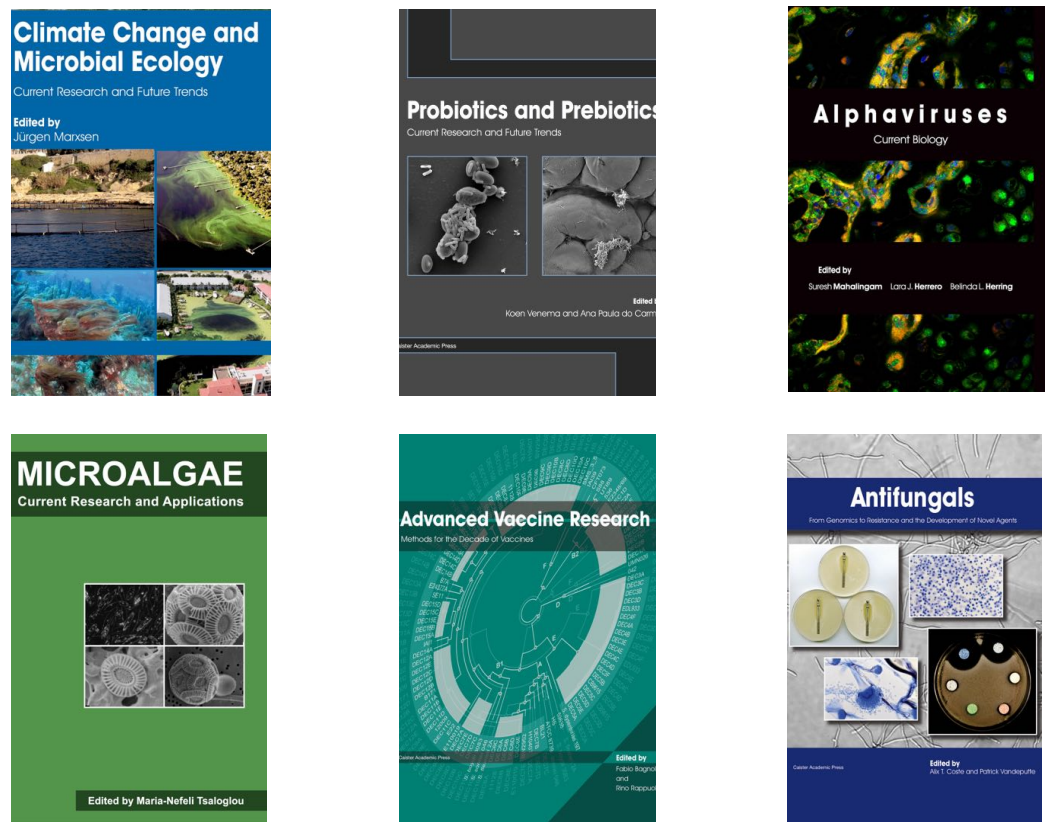

- Flow Cytometry in Microbiology: Technology and Applications Edited by: MG Wilkinson (2015) www.caister.com/flow

- Probiotics and Prebiotics: Current Research and Future Trends Edited by: K Venema, AP Carmo (2015) www.caister.com/probiotics

- Epigenetics: Current Research and Emerging Trends Edited by: BP Chadwick (2015) www.caister.com/epigenetics2015

- Corynebacterium glutamicum: From Systems Biology to Biotechnological Applications

Edited by: A Burkovski (2015)

www.caister.com/cory2

- Advanced Vaccine Research Methods for the Decade of Vaccines

Edited by: F Bagnoli, R Rappuoli (2015)

www.caister.com/vaccines

- Antifungals: From Genomics to Resistance and the Development of Novel Agents

Edited by: AT Coste, P Vandeputte (2015)

www.caister.com/antifungals

- Bacteria-Plant Interactions: Advanced Research and Future Trends Edited by: J Murillo, BA Vinatzer, RW Jackson, et al. (2015) www.caister.com/bacteria-plant

\section{- Aeromonas}

Edited by: J Graf (2015)

www.caister.com/aeromonas

- Antibiotics: Current Innovations and Future Trends

Edited by: S Sánchez, AL Demain (2015)

www.caister.com/antibiotics

- Leishmania: Current Biology and Contro Edited by: S Adak, R Datta (2015) www.caister.com/leish2

- Acanthamoeba: Biology and Pathogenesis (2nd edition) Author: NA Khan (2015)

www.caister.com/acanthamoeba2

- Microarrays: Current Technology, Innovations and Applications Edited by: Z He (2014)

www.caister.com/microarrays2

- Metagenomics of the Microbial Nitrogen Cycle: Theory, Methods and Applications

Edited by: D Marco (2014)

www.caister.com/n2 